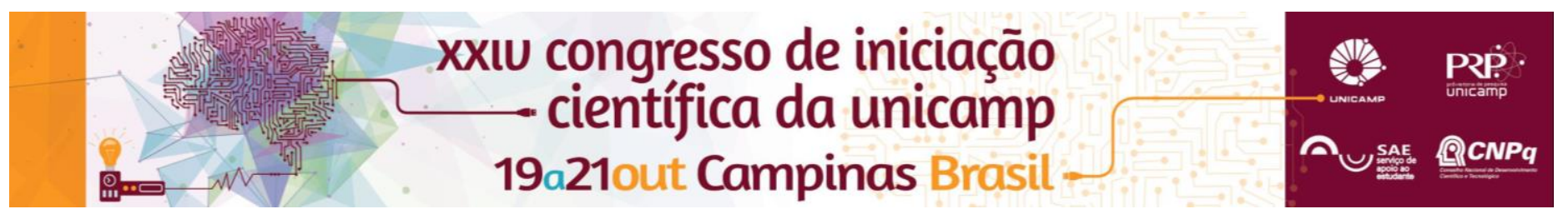

\title{
A liquidez internacional e os efeitos sobre a conta financeira brasileira.
}

\section{Guilherme A. Prado*}

\section{Resumo}

A liquidez internacional determina o volume e a direção dos fluxos de capital, entretanto ela depende das politicas monetarias dos países centrais que trancendem o plano nacional e da aversão ao risco dos agentes internacionais que na busca por maior rentabilidade podem causar grande volatilidade macroeconômica em países periféricos como o Brasil.

\section{Palavras-chave:}

Fluxo de capitais, Conta Financeira, Liquidez.

\section{Introdução}

A liquidez global pode ser definida como a facilidade de obtenção de financiamento no sistema internacional, ela determina o volume e a direção dos fluxos de capital, mas também a dinâmica de certos preços, dentre os quais, as taxas de câmbio. Sua abundância é capaz de criar vulnerabilidades no sistema financeiro global já que a ampla disponibilidade e possíveis menores custos podem gerar a apreciação de certas moedas dependendo da sua posição na hierarquia monetária $^{1}$, a alavancagem de setores específicos e a alocação de recursos em atividades improdutivas com fins especulativos. Isso pode ter contribuído para aumentar a fragilidade do país e consequentemente deve ser analisada de perto, já que a suas políticas monetária, fiscal e cambial podem ter dificuldade em lidar com as oscilações entre surtos de oferta e escassez de liquidez gerando uma volatilidade macroeconômica.

\section{Resultados e Discussão}

Antes da eclosão da crise financeira, em 2008, pode-se definir duas fases distintas ${ }^{2}$ do ponto de vista da liquidez para países periféricos: uma fase de "cheia" e outra de "seca", em relação a abundância de liquidez para países periféricos. Um primeiro ciclo se entre o início da década de 1990 e o ano de 2002; e um segundo se iniciando em 2003 e terminando em 2008. Uma nova fase se inicia após a crise e tem como diferenças em relação as anteriores uma alteração na fonte de credito, o crescimento do mercado de títulos. Para se acompanhar esse movimento da liquidez internacional foi utilizado o índice de VIX, ou "índice do medo", que é uma proxy internacional da aversão ao risco baseado no índice da Standard \& Poor's 500 que se move inversamente ao mercado de ações, ou seja, quanto maior o índice, maior o medo e a aversão ao risco fazendo com que a oferta de credito caia e consequentemente diminuindo a liquidez global. $O$ período após a crise mundial apresentou um elevado índice de VIX, uma alta aversão ao risco acompanhado da redução de oferta de liquidez global pelos mercados interbancários americano e europeu. Embora as decisões do FED em diminuir as taxas de juros americanas para estimular a economia significassem um escoamento dos recursos para o país ela também representou um movimento dos recursos para os países periféricos como o Brasil, que mesmo apresentando maiores riscos, atraíram o capital que procurava por melhores remunerações.
Gráfico 1. Fluxo de Capitais no Brasil (US\$ milhões)

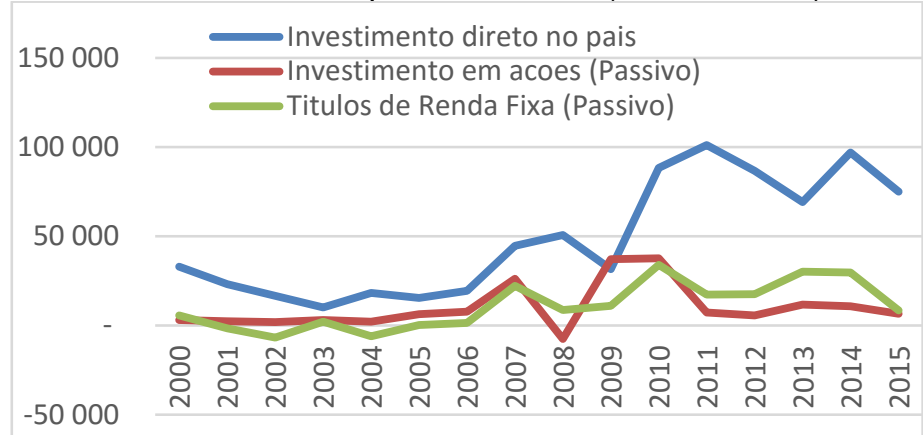

Gráfico 2. Índice de VIX

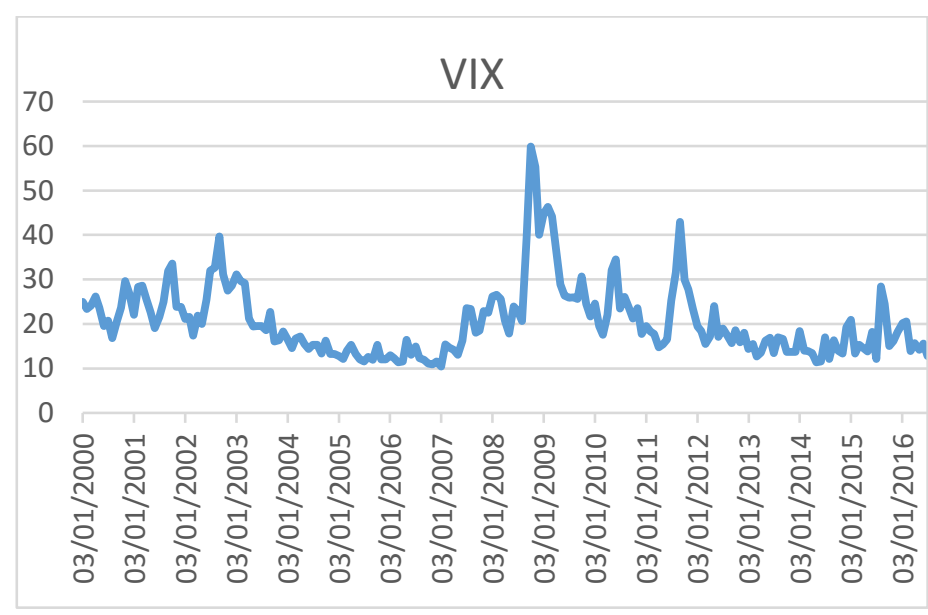

\section{Conclusões}

A partir dos gráficos é possível constatar que o Investimento direto no país, anteriormente de IED, é o principal destino dos fluxos de capitais que entram no Brasil e representa um investimento muito mais estável. Contudo, a instabilidade mundial, as decisões econômicas dos países centrais e a alta aversão aos riscos, faz com que investimentos mais voláteis (ações, títulos) sejam preteridos devido a rentabilidade elevada e maturidade mais curta. Isso demonstra a natureza especulativa e volátil dos fluxos de capitais quando na presença dessas condições.

\footnotetext{
Prates, D. M. Crises financeiras dos países “emergentes": uma interpretação heterodoxa. Ie/Unicamp: Tese de doutoramento, 2002.

2 Biancarelli, André. Integração, Ciclos e Finanças domésticas: O Brasil na Globalização Financeira. Ie/Unicamp: Tese de doutoramento, 2007.
} 